\title{
A Small Step from Price Competition to Price War: Understanding Causes, Effects and Possible Countermeasures
}

\author{
Andreas Krämer ${ }^{1,2}$, Martin Jung ${ }^{2} \&$ Thomas Burgartz ${ }^{1}$ \\ ${ }^{1}$ BiTS, Business and Information Technology School, Iserlohn, Germany \\ ${ }^{2}$ Exeo Strategic Consulting AG, Bonn, Germany \\ Correspondence: Andreas Krämer, Exeo Strategic Consulting AG, Wittelsbacherring 24, 53115 Bonn, Germany. \\ Tel: 49-178-256-2241. E-mail: andreas.kraemer@exeo-consulting.com
}

Received: December 21, 2015

Accepted: January 15, 2016

Online Published: February 25, 2016

doi: 10.5539/ibr.v9n3p1

URL: http://dx.doi.org/10.5539/ibr.v9n3p1

\begin{abstract}
The first part of this paper describes the characteristics of price wars, pointing to recent examples that have caused a stir among the public as well as in the respective industries. A new, concise definition of the term price war is suggested. In the second part drivers for price wars are discussed and explained based on behavioral economics (understanding the competitor's strategy as well as a company's own cost situation). Particularly in industries that are characterized by a high proportion of costs that are unchangeable in the medium-term and low variable costs there is a substantial risk for unintended price competition possibly ending in a price war. Even slight price reductions can have fatal consequences when decision makers mistakenly estimate the price elasticities too high. In the third part a case study of a price war is presented by focusing on the market of long-distance bus journeys in Germany. Since the market for intercity bus connections was liberalized in 2013, the newly created market segment faces a very strong growth and intensive competition. Using a multi-source-multi-method-approach it is shown how the market entry of UK-based company Megabus affected price levels for bus journeys und initiated competitive reactions of the German railway operator Deutsche Bahn. The interaction of various parameters (low barriers to enter the market; high similarity of products/services; fixation on market share and capacity utilization) leads to a ruinous price competition and leaves few chances for a sustainable profitability. Measures to avoid an impending or to terminate an ongoing price war are presented.
\end{abstract}

Keywords: price competition, price war, signaling, cost-structure, long-distance bus connections, VUCA

\section{Introduction}

\subsection{Price War: A Typical Phenomenon in Many Industries?}

An often cited example for a price war: In 1992, a fierce price war on bus services between New York City and Washington D. C. was initiated by Peter Pan Trailways, after acquiring a Washington D. C. terminal. Peter Pan lowered their initial fare of $\$ 25$ to $\$ 9.95$, to "turn some heads". Their main rival, Greyhound, responded by cutting their fare to $\$ 7$, whereupon Peter Pan lowered its fare to $\$ 6.95$. Greyhound pushed its fare to $\$ 5$ (which was less than Greyhound had charged 40 years before). Peter Pan immediately matched, resulting in both firms operating below cost price.

The phenomenon of intensified price competition is increasingly typical in many industries (Simon, 2013). In 2015 alone, a number of examples can be found where the market situation is described as price war (see Table 1). These include examples from the airline industry as well as IT and Computing. A particularly strong discussed case with worldwide economical relevance is the decline in crude oil prices. The oversupply of oil is less a coincidence, but rather based on strategic considerations of the major providers.

There are several major factors that motivate a competitor to start and likely win a price war. (1) Excess capacities raise the question, whether there are ways to significantly increase sales. A dominant company owning more than 50 percent market share in a profitable industry is a prominent indicator for a highly probable price war, since it carries more risks for a dominant company to initiate or respond to price decreases. (2) Managers increasingly face the risk of commoditization. As a recent study of Roland Berger (2014) shows, $60 \%$ of managers believe they are caught in a "commodity trap" (a situation where even complex products and services are downgraded to "commodities", with limited differentiation and a competition that is primarily price-based). 
(3) In many new markets, lowering prices makes the market grow more quickly. The flat-screen TV market is a recent example where the prices started at a high level and as the prices fell, more and more people demanded and purchased flat-screen TV's-the market grew. (4) Lower costs might play a role: If a company can dramatically lower its costs by increasing volume, then it is more likely to start a price war. Ryanair is a good example. The airline is attacking traditional full-service airlines by offering lower fares (low costs per passenger seat are a precondition). Additional factors are a large concentration of market share, new market entrants, exit barriers and price leadership (Heil \& Helsen, n. d.).

\subsection{Research Questions}

As these examples illustrate, price war as a term is more frequently used when describing aggressive price competition and businesses affected can strongly suffer from price wars. This raises the following questions:

1) What is a suitable definition of a price war? Particularly, how can the terms price competition and price war be marked-off?

2) How do price wars typically start (what drives the company that triggers a price war) and what are the outcomes? How can both perspectives be combined to classify price wars?

3) Do managers' perceptions of the firm's cost-situation influence decisions to lower the price and initially trigger a price war?

4) Do typical elements of a price war apply to the case of the liberalized market for intercity bus connections in Germany?

5) Which approaches should managers use to avoid or terminate price wars?

Table 1. Examples for price wars in 2015

\begin{tabular}{|c|c|c|c|}
\hline Industry & Situation & Country & Source \\
\hline $\begin{array}{l}\text { Retail / } \\
\text { supermarkets }\end{array}$ & $\begin{array}{l}\text { “Asda fires first in supermarkets’ } 2015 \text { price war”; “...Asda } \\
\text { announced to plough } £ 300 \mathrm{~m} \text { into lowering the price of } 2,500 \\
\text { essentials-Sainsbury’s followed” }\end{array}$ & UK & $\begin{array}{l}\text { The Guardian (Jan } \\
6,2015 \text { ) }\end{array}$ \\
\hline $\begin{array}{l}\text { Crude oil / } \\
\text { commodities }\end{array}$ & $\begin{array}{l}\text { "Saudis Oil Price War Is Paying Off" } \\
\text { "A year ago Saudi Arabia refused to allow OPEC to try to raise } \\
\text { prices ..., in the hope that a low price would drive competitors ...out } \\
\text { of business" }\end{array}$ & $\begin{array}{l}\text { OPEC / KSA / } \\
\text { U.S. }\end{array}$ & $\begin{array}{l}\text { Bloomberg (Feb 27, } \\
\text { 2015); The } \\
\text { Economist (Nov 14, } \\
\text { 2015) }\end{array}$ \\
\hline Cloud computing & $\begin{array}{l}\text { "This One Chart Shows The Vicious Price War Going On In Cloud } \\
\text { Computing": “... Amazon Web Services, for example, has cut its } \\
\text { price } 44 \text { times in the last six years, while Microsoft and Google } \\
\text { have both decreased prices multiple times" }\end{array}$ & U.S. & $\begin{array}{l}\text { Business Insider } \\
\text { Jan 14, } 2015\end{array}$ \\
\hline $\begin{array}{l}\text { Airline / travel } \\
\text { industry }\end{array}$ & $\begin{array}{l}\text { "Is a Price War Brewing in the Airlines Industry? And that is after } \\
\text { the airline added } 6 \% \text { to its capacity in the first quarter of this year" }\end{array}$ & U.S. & $\begin{array}{l}\text { 247wallst.com, May } \\
20,2015\end{array}$ \\
\hline
\end{tabular}

\subsection{Definition of a Price War}

Price wars describe a scenario where competing firms are struggling to undercut one another's prices (Assael, 1990). Urbany and Dickson (1991) refer to a "price-cutting momentum," or the downward price pressure that drives other competitors to follow the initial move. Busse (2000) asserts that a "price war is a period in which the firms set prices that are significantly below the prices typically charged in the industry." Unlike any other form of competition, including intense price competition (Schunk, 1999), price wars entail market-death. That suggests, as a major characteristic, that price war-type competition is not sustainable over time. According to von Clausewitz (1832/1984), this corresponds with the "destruction of the fighting force", the competitor is "put in such a condition that he can no longer carry on the fight." In the example of the ongoing price war between the OPEC-countries, led by the Kingdom of Saudi Arabia (KSA), and the United States, the similarities are evident: By lowering the prices the OPEC-countries try to subdue the U. S. oil industry. As the U. S. are mainly producing cost-intensive shale gas, the effort shows first success: The U.S. shale gas industry consolidates itself, many smaller producers are "subdued" and "destroyed", the bigger ones survive due to their increased efficiency. The OPEC, especially the KSA, is able to produce oil for way lower prices than the shale gas industry and thereby is - to a certain extent - able to destroy its enemies (see Note 1).

After an extensive review of business press articles and academic literature, Heil and Helsen (2001) define a 
price war as requiring one or more of the following conditions: (1) There is a strong focus on competitors rather than on consumers, (2) the pricing interaction as a whole is undesirable to firms, (3) the competitors neither intend nor expect to ignite a price war, (4) the competitive interaction violates industry norms, (5) the pricing interaction occurs at a much faster rate than normal, (6) the direction of pricing is downward, and (7) the pricing interplay is not sustainable.

Yet it is not clear how a scenario of price war differs from price competition. While price competition means that the factor price plays a crucial role in the competitive environment, what is additionally necessary to fulfill the characteristics of a price war? There are doubts whether a situation with a strong focus on competitors rather than on consumers (condition 1) is sufficient to define a price war. Typical players in oligopolistic markets (airlines, gas stations) have a strong focus on competitor's action. Therefore price-matching plays a crucial role in these industries. However, this does not necessarily proof the existence of a price war. The same applies for the element "the direction of pricing is downward" (condition 6). In order to clarify, a more specific definition is needed. We define a price war as a scenario, when (1) market players try to win market share by utilizing aggressive pricing taking into account potential losses in short term, (2) prices are undercut to fall below the level of industry profitability (at least for main players in the market) and (3) actions are driven by suppliers rather than consumers. Even if the step between price competition and price war should be small, it can be clearly explained on the basis of this definition.

\subsection{Structure to Classify Price Wars}

As Rao, Bergen, \& Davis (2000) point out, "generally, price wars start because somebody somewhere thinks prices in a certain market are too high. Or someone is willing to buy market share at the expense of current margins." This implies a certain rationality that might not always exist. While terms as predatory pricing (Tellis, 1987) and tit-for-tat pricing reactions (Rao, Bergen, \& Davis, 2000) suggest that the start of a price war is a conscious act of the management, there is evidence that a significant share of all so-called price wars are initiated by untargeted decisions. Following a different opinion (Pot et al., n. d.) it is although arguably possible that parties in conflict are thrown into a price war without their consent. Then, price wars are deliberately initiated by one of the firms in the market.

Table 2. Outbreak and outcome of a price war

\begin{tabular}{|c|c|c|c|}
\hline \multicolumn{4}{|c|}{ Outcome of a price war } \\
\hline \multirow{5}{*}{$\begin{array}{l}\text { Trigger of the } \\
\text { price war }\end{array}$} & & Negative (company A) & Positive (company A) \\
\hline & Untargeted decision & (1) Disaster & (2) Luck \\
\hline & (company A) & ("We did not want that)" & ("Somehow we survived") \\
\hline & Targeted decision & (3) Miscalculated & (4) Strategic price war \\
\hline & (company A) & (“Our assumptions were wrong”) & ("We executed like planned") \\
\hline
\end{tabular}

Genenz, Lopez-Sors, and Alencar (2014) discuss three different myths which explain the beginning and the outcome of a price war. Managers assume that a price decrease will increase demand for their products and fail to understand that the consequence will be a volume increase on the one hand and a margin decrease on the other hand. According to Simon-Kucher's Global Pricing study (Bertini, 2014), when managers were asked who started the price war, almost $90 \%$ of them answered: "it was the competitor." This leads to the assumption that most price wars are started untargeted. Managers misunderstand that they are part of the cause, believing they take just a reactive part. Even worse, the decision makers expect prices to increase, once the price war is terminated. If this is not the case a critical profit situation might endure over a longer time period. This scenario (1) is shown in Table 2.

A different scenario is given when a company is consciously willing to start a price war: According to van Heerde, Gijsbrechts, and Pauwels (2008), Albert Heijn decided to slash its prices for more than 1,000 products on October 20, 2003, aiming to end a trend towards sliding market share, using the headline "From now on, your daily groceries are much less expensive". The overall result for the industry was disastrous: The loss in added value for the Dutch retailing industry was estimated to be $€ 900$ million in one year, and more than 30,000 employees in the grocery industry lost their jobs (Van Aalst, 2006). The initiator's market share increased but at the expense of profits; the price war decreased spending at Albert Heijn at the same rate as at the market average. Overall, there was no clear victory for the retailer (Heerde, Gijsbrechts, \& Pauwels 2008). The price war finally made consumers more sensitive to weekly prices and price image, which helped both the chain that showed an 
improvement in price image (the price war initiator) and the chains that already had a favorable price image (discounters).

While in the West academic researchers and practitioners regard price wars in an industry as the failure of managerial rationality, Chinese companies obviously do not share the same code of business conduct. As Zhang (2008) demonstrates, Chinese companies seem to have a talent in identifying those opportunities and seizing upon them. He presents two examples of Chinese companies that initiated a price war (color TV industry and microwave oven industry) and finally improved their market position and profitability. This represents the scenario of a targeted price war with a positive outcome for the initiator (see Table 2). One has to keep in mind that the situation in China has some specific elements due to large growth rates in many sectors.

\section{Methodological Background}

\subsection{Simple Behavioral Model to Simulate Pricing Decisions}

In the second part drivers for triggering price wars are discussed and explained using behavioral economics (understanding the competitors strategy as well as the own cost situation). Therefore a simple example is presented, indicating situations when pricing decisions are made. The framework of pricing decisions (market understanding, assumptions etc.) is presented as well as the consequences for main parameters such as sales, gross margins and profits.

\subsection{Multi-Method-Multi-Source-Approach}

Two different approaches were selected to provide insights into the price mechanism in the German market for long distance bus trips: (1) an own survey and (2) data observations of available prices. MobilityTrends 2015 is a study to identify and assess trends in the mobility industry. It is carried out several times a year in cooperation between exeo Strategic Consulting AG and Rogator AG. The study is based on a representative survey of 4,500 persons aged 18+ years (German-speaking population DACH region). Those who made trips of more than $50 \mathrm{~km}$ (one way) in the last 12 months are the core target group of the study. The latest survey (Sep./Oct. 2015) contained a special block of questions addressed to users of long-distance buses. The target group is $\mathrm{n}=378$ individuals who have made at least one trip in a long-distance bus in the last 12 months.

A price monitoring took place by observing 10 representative routes for a bus trip. For a defined departure day (Tue, October 27, 2015) all available rates of different bus suppliers as well as Deutsche Bahn (railway) were apprehended. The observation included 21 days until shortly before departure. For 5 of these routes the new entrant Megabus also offers bus trips.

\section{Using Behavioral Economics to Understand the Beginning of Price Wars}

\subsection{Decision Making under Uncertainty}

The challenge for decision makers in pricing becomes more sophisticated: Sometimes original expectations regarding the effects of management decisions on the perception of customers, competition, sales and profits as well as the public opinion were overtaken by reality, with fatal consequences for the financial situation of the companies concerned. This is described with the term VUCA (Krämer, 2015a):

(1) Volatility: Compared to the situation a decade ago, it is now acknowledged that not only more price decisions are made, but they are also made much faster. One driving factor is the massively increased availability of Internet-access and the associated new marketing opportunities. At the same time Internet marketing allows a determination of the price and rapid price changes (Vanek-Smith, 2012). Pricing robots at the same time increase price transparency and make comparisons of price easy for everyone.

(2) Uncertainty about the present situation and future options: A key issue managers face today is to recognize that uncertainty regarding strategic decisions can be reduced but will however leave room for interpretation at the end of the day. In this context factors arise that can influence the management only to a small extent.

(3) Complexity: In contrast to the simplistic focus on the consumers' willingness to pay when predicting the impact of price variations on sales and profits, in practice more dependencies exist that make the decision making increasingly complex.

(4) Ambiguity (lack of clarity about the meaning of an event): Another difficulty arising from the combination of factors such as (a) speed of decisions, (b) volume and inconsistency of data and (c) sense of a permanent pressure to act, is the right and quick interpretation of signals from the market

\subsection{Underestimation of Price Elasticity}

Studies show that the proportion of companies with global operations, who see themselves in a price war, has 
increased from 46\% (2011) to 59\% in 2012 (SKP 2013). Price wars are becoming more common because managers tend to view a price change as an easy, quick, and reversible action (Rao, Bergen \& Davis, 2000).

As an example, we assume a situation in which a provider (A) realizes a price of $\$ 100$ in the initial situation and thereby settles 50,000 units. The variable cost per unit is $\$ 10$. With sales of $5.0 \mathrm{~m}$ units a contribution margin of $\mathrm{m} \$ 4.5$ is generated. In addition, fixed costs of $\$ 3.0 \mathrm{~m}$ have to be considered. This leads to a profit of $\$ 1.5 \mathrm{~m}$ for company A, which corresponds to a profit margin of $30 \%$ (Figure 1, scenario 1).

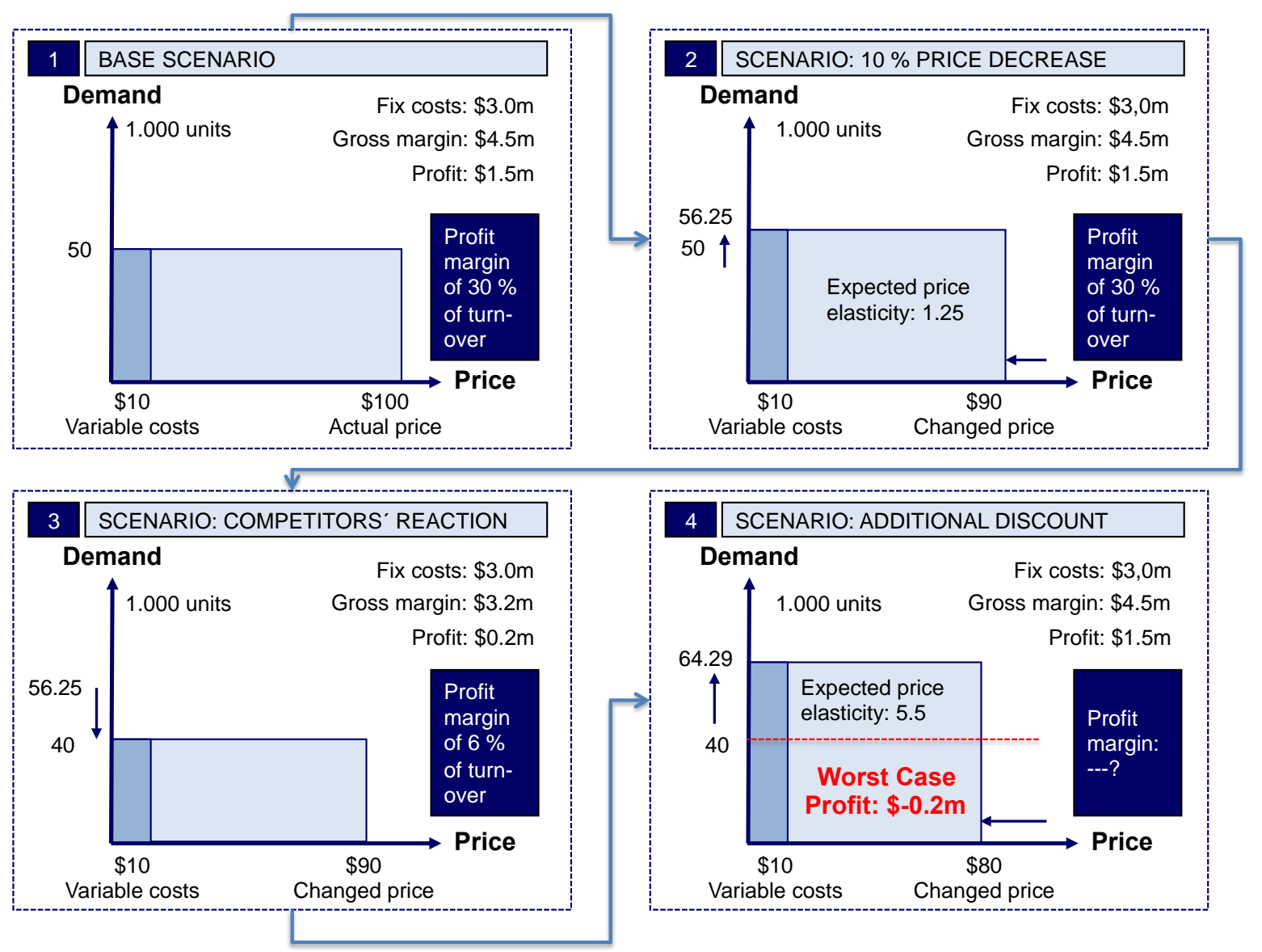

Figure 1. Price reduction as a dynamic process

The crucial point for triggering the price war comes when the management is discussing options to increase the market shares of the company through a "slight price reduction". The decision-makers are convinced that a reduction of the price by $10 \%$, will improve both the short-term market share as well as the long-term profitability of the company. Management expects to sell at least 56,250 units in the following period, assuming that at least the current profit situation is maintained (scenario 2).

Competitor B feels strongly attacked by the price reduction and feels compelled to respond as quickly as possible on this "attack", while so far "creeping" market share losses were accepted. Subsequently, the management of company B decides to undercut the price level of company A in order to restore the old situation. As a consequence, results for company A are unexpected: although the price was lowered, demand decreases to an amount of 40,000 units. This leads to shrinking revenues of $\$ 3.6 \mathrm{~m}$, gross margin of $\$ 3.2 \mathrm{~m}$ and profits of $\$ 0.2 \mathrm{~m}$. All of a sudden, the company's profitability is considerably reduced (6\% return on sales).

Even worse, for the company A it becomes obvious that a significantly higher price elasticity is required to at least restore the original status in a further price reduction (for example, from $\$ 90$ to $\$ 80$ ). However, the management also faces the risk that competitor B in turn follows with lowered prices and once again there is no real increase in sales. In this worst-case scenario company A has no chance to generate profits: Losses will be $\$ 0.2 \mathrm{~m}$. 
This example illustrates typical elements of a price war:

(1) Company A has not deliberately triggered a price war, although this was objectively the case. The reason is that suppliers A and B evaluate the price reduction contradictory. However, company A could at least have partially anticipated its competitor's reaction. This assumes, however, that the management has to be aware of the strategies the main competitors are pursuing.

(2) Within few steps of price-cutting the industry's profitability can be destroyed. In addition, there is the question whether, after another price reduction of company A to $\$ 80$ retaining the previous price level $(\$ 100)$ is possible once the price war is over.

(3) Due to low variable costs per unit management is tempted to a price reduction. This can easily be illustrated when the variable costs are much higher (i.e. $\$ 80$ ) instead of $\$ 10$. In this case, the break-even for the sales volume is 100,000 units, corresponding with an unrealistic price elasticity of 10 ! Particularly in industries that are characterized by a high proportion of medium-term unchangeable costs and low variable costs there is an increased risk for an unplanned triggering of price competition.

\section{Case Study on Price Wars: Intercity Bus Connections in Germany}

\subsection{Market Developments and Competitive Environment Concerning Trips by Bus and Rail}

The following aspects can illustrate the dynamic market development for trips with long-distance buses:

(1) Strong capacity extension until 2015: The number of routes increased by more than $100 \%$ from 113 (April 2013) to 264 (April 2015); the development of the market for intercity bus trips received an additional boost and high public awareness through lengthy and frequent strikes at Deutsche Bahn (QI/QII 2015). According to the Federal Statistical Office approximately 16 million trips by long-distance buses were booked in 2014, with an average distance of about $300 \mathrm{~km}$ (Table 3). Today, 85 percent of the German population is aware of the intercity buses. In 2014, nearly 4 million people conducted at least one trip using long-distance buses (Krämer \& Rieger, 2015).

Table 3. Market development German rail and intercity bus services (2012-2014, journeys)

\begin{tabular}{lllll}
\hline Carrier & 2012 & 2013 & 2014 & Delta 2014-12 \\
\hline Intercity bus services & $3.0 \mathrm{~m}$ & $8.2 \mathrm{~m}$ & $16.0 \mathrm{~m}$ & $13.0 \mathrm{~m}$ \\
German Rail (long-distance traffic) & $130.5 \mathrm{~m}$ & $130.6 \mathrm{~m}$ & $129.0 \mathrm{~m}$ & $-1.5 \mathrm{~m}$ \\
Total (long-distance traffic) & $133.5 \mathrm{~m}$ & $135.0 \mathrm{~m}$ & $145.0 \mathrm{~m}$ & $11.5 \mathrm{~m}$ \\
\hline Market share bus & $2 \%$ & $6 \%$ & $11 \%$ & $9 \%$-points \\
\hline
\end{tabular}

(2) Change in the supply structure: On the one hand, some vendors showed severe financial problems at the end of 2014 (the company "DeinBus" opened an insolvency proceeding; the company "City2City" ceased their offer in Germany). On the other hand, there were changes in the ownership structure (exit of the ADAC from the cooperation "ADAC Postbus" and merger of two leading companies "MeinFernbus (MFB)" and "FlixBus" early in 2015). After the merger of the two by far largest bus providers - MFB and FlixBus - a general rise in price levels had widely been expected for the following months. As it turned out, a real price increase, however, was not observed (Anonymous, 2015). Additionally, due to the market entry of Megabus (April 2015), a new momentum emerged in the market.

(3) Price competition: The strong demand growth was also driven by a price-competition of the suppliers, although all providers as well undertook an attempt to differentiate their products and services. A recent study (VCD, 2014), which compared rail- and bus-rates, concludes that on $94 \%$ of the tested routes the intercity bus connection was the cheapest mode of transport. Since the market entry of Megabus clear indicators of a price war became apparent. Megabus' communication is clearly focused on reference prices (price from $€ 1$ per trip). Thereby the entrant considerably reduced the already low level of prices of providers of distance bus trips.

Overall, the evaluation of the price-performance ratio of the intercity bus in comparison to other means of transport is very good (Figure 2): 


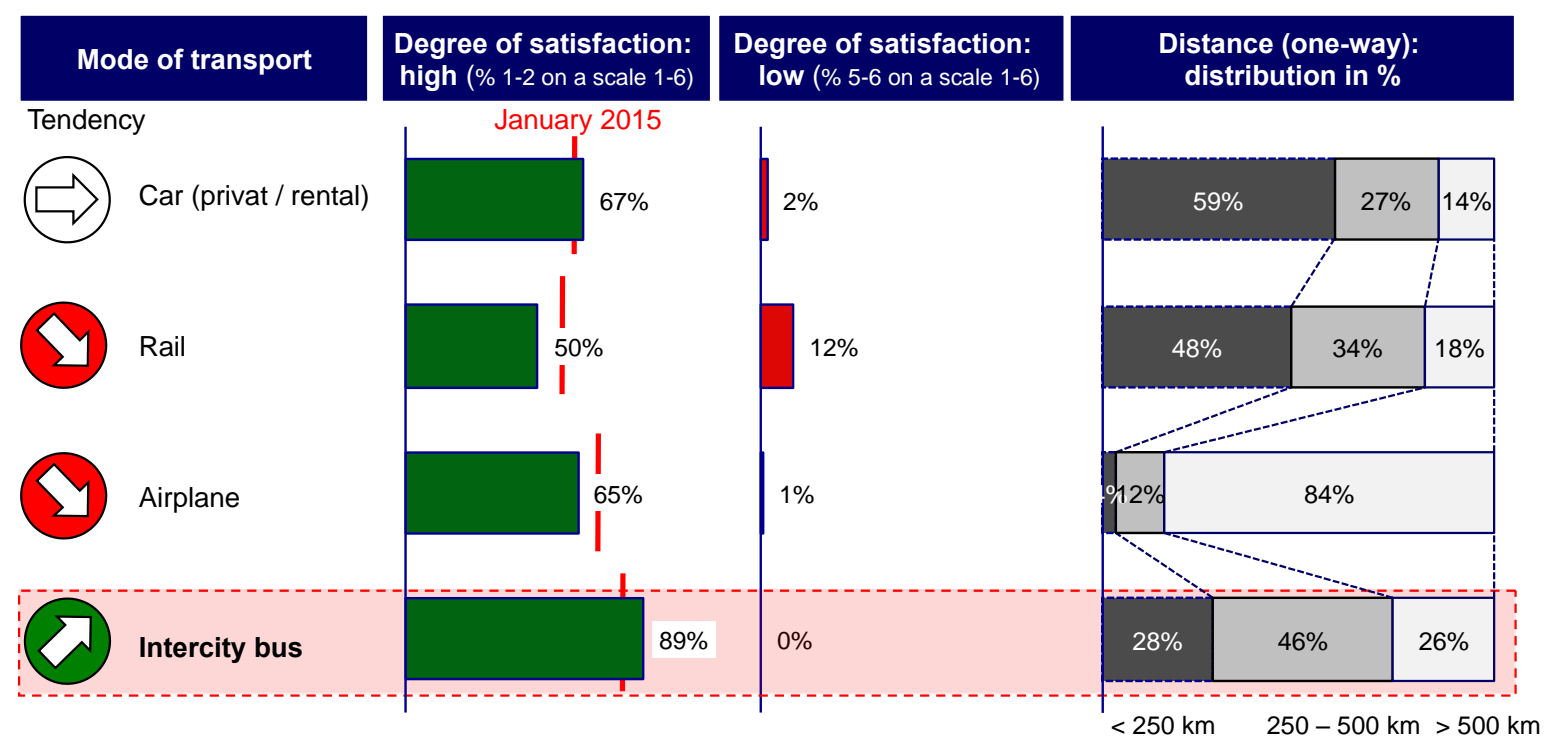

Figure 2. Degree of customer satisfaction (value for money) for different modes of transport; Germany Sep. 15

Based on empirical data, the German Federal Office for Goods Transport comes to the conclusion that "the lower end of the observed price range was below the cost recovery limit" (BAG, 2014, see Note 2).

\subsection{Comparison of Available Prices of Relevant Intercity Buses and Rail Competitors}

Several studies conclude that the railway system is substituted in a particular degree through distance buses (Krämer \& Rieger, 2015). Contrary to the widespread notion that intercity bus would primarily generate new demand and in particular "redirect" car trips to eco-friendly intercity bus connections (Von Hirschhausen \& Walter, 2008); buses and railways find themself in the strongest competition. This is not surprising, as the railway systems and long-distance buses basically have very similar production systems and customer target groups.

A comparison of the available rates for Megabus (market entrant intercity buses) and MFB FlixBus as a market leader (intercity buses) as well as the Deutsche Bahn (railway) on 5 major routes shows the following results (see Table 4):

(1) Among the main suppliers Megabus offers by far the lowest rates. If booked early (21-12 days prior to departure), customers pay on average $€ 3.40$ per trip. Until shortly before departure average prices rise to $€ 5.70$ (increase of 67\%). Nevertheless, the absolute price level remains low.

(2) Over the entire investigation period, prices of MFB FlixBus (market leader) remain very constant at $€ 17.80$ per trip and are therefore at least $200 \%$ higher than the price of Megabus.

(3) The German Rail (DB) offers by far the highest prices. However, a significantly shorter travel time has to be considered. Shortly before departure, the average price of DB is about $€ 70$ and thus $€ 52$ higher than the most expensive fare of the intercity buses.

(4) Concerning the yield per $\mathrm{km}$ Megabus reaches the lowest values (0.82 to $1.35 \mathrm{cents} / \mathrm{km}$ ). Additional indications for the degree of utilization are the number of available seats shortly before departure. Based on these data, for both vendors a low to medium capacity utilization can be estimated: Megabus (larger capacity) and MFB FlixBus (medium capacity) both have spare seats. This is a possible explanatory factor for the low variance in prices.

Interestingly, the prices of trips with long-distance buses on routes where Megabus does not offer tickets are higher (prices shown in Table 4) compared to routes with Megabus supply (see Note 3). But again: The observation of available prices hardly shows a variation. Also typical increasing price functions while approaching the day of departure are barely observed. 
Table 4. Available prices for intercity bus services and German rail tickets (observed available prices)

\begin{tabular}{lcccc}
\hline 5 different O\&D's & \multicolumn{4}{c}{ Available prices in EUR per trip (one-way, average distance $419 \mathrm{~km}$ )* } \\
(October 2015) & $21-12$ days to dep. & $11-4$ days to dep. & 3-1 days to dep. & Free Capacity** \\
\hline Megabus & $3.4(0.82)$ & $4.9(1.16)$ & $5.7(1.35)$ & 67 Seats \\
MFB FlixBus & $17.8(4.25)$ & $17.8(4.25)$ & $17.8(4.25)$ & 27 Seats \\
German Rail & $52.4(12.50)$ & $61.6(14.69)$ & $69.7(16.63)$ & n.a. \\
\hline
\end{tabular}

Note. $*()=$ Available prices EUR Ct/km (Yield) per trip ** Shortly before departure.

\subsection{Increased Price Erosion and Competitive Price Promotions}

Consolidating the data from the price monitoring on the one hand and surveys of potential customers for long-distance bus trips on the other hand completes the overall picture with regard to the competitive positioning of the different suppliers (Figure 3).

For a typical journey of $300 \mathrm{~km}$ (one-way) the average price for a bus trip is $€ 18$. Taking into account the lowest available fare, tickets are already available and purchasable from $€ 3$ (corresponding to 1 Cent per kilometer). Both price points are far below the average price, which potential travelers perceive as cheap for a bus trip ( $€ 24$, open-ended question, see Note 4).

A different picture emerges for the saver ticket of Deutsche Bahn ("Sparpreis"). Usually, available rates are around $€ 32-€ 35$ per one-way ticket. This represents a price of about 11 Cent per kilometer. For German Rail operator Deutsche Bahn (DB) the average point of cheapness was determined and quantified to be $€ 31$ on average. The fact that the average point of cheapness significantly differs between bus and train can, to some extent, be explained by the significantly shorter travel time by train.
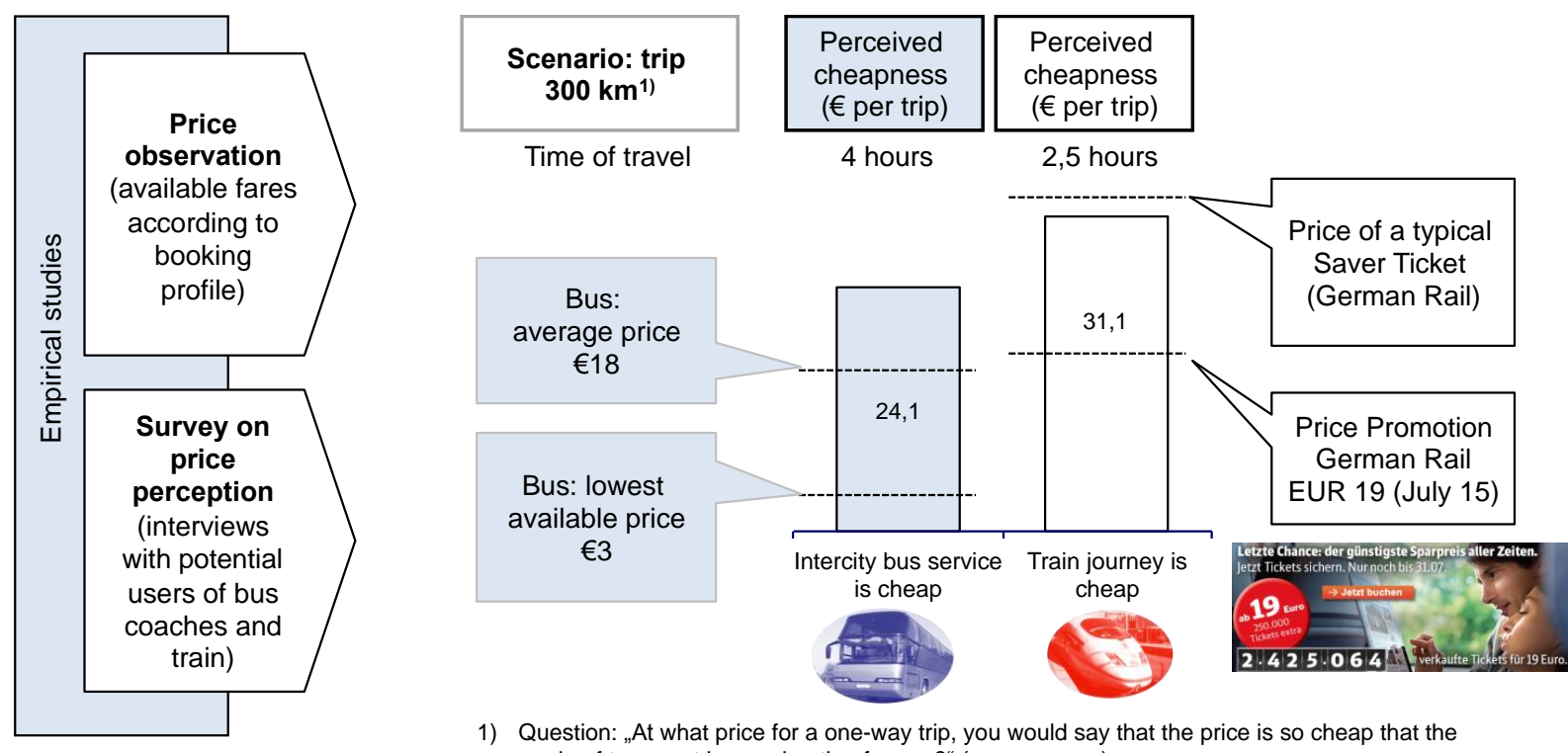

1) Question: „At what price for a one-way trip, you would say that the price is so cheap that the mode of transport is a real option for you?" (open answer)

Figure 3. Market prices for intercity bus and rail trips and perceived cheapness by the consumer (2015)

After DB initially has announced it would not respond to any aggressive pricing of a bus competitor, the pressure on the management in 2015 has grown significantly (it became public that in the current fiscal year DB will not generate profits for the first time in 10 years). Subsequently, the sales promotion "cheapest special fare ever" $(€ 19)$ was advertised in June 2015. Within a few weeks, about 2.4 million tickets were sold. Taking into account additional discounts (BahnCard, multi-person-discounts) effective rates of $€ 14$ or lower were possible, corresponding with 3 Cent per kilometer (i.e. lower than the average available prices of long-distance buses). 


\section{Approaches to Avoid and Terminate Price Wars}

Although, due to a more competitive environment and technological progress, price competition will become more frequent, there are measures to avoid price wars (pre price war phase) or terminate a price war (price war has already started). Additionally, one might differentiate between pricing and non-price actions (Table 5).

\subsection{Pricing Measures}

Employing complex options such as volume discounts or bundling can reduce price transparency and offer significant customer value at the same time. McDonald's applied these tools successfully when it faced Taco Bell's 59-cent taco strategy in the 1980s. By bundling burgers, fries, and drinks into "value meals," McDonald's reframed the price war from "tacos versus burgers" to "lunch versus lunch" (Rao et al., 2000). Postbus, a major supplier of bus trips in Germany, has introduced a discount-card and changed its pricing structure. Starting in October 2015 passengers with a "Postbus Card" can book bus tickets at a $25 \%$ discount. The card is sold for $€ 25$ per year (see Note 5).

In addition, companies should try to identify opportunities for selective price increases, at least for individual customer groups or at certain periods. Erratic price increases occurred in mid-2015 after the German rail service was strongly restricted by strikes. However, after the merger of both companies market leader MFB FlixBus missed chances to take over the function of the price leader and adjust the price level upwards. As surveys indicate (potential) customers mostly expected this step (Rogator \& exeo, 2015; see Note 6). Again, this indicates that the current price level provides an enormous consumer surplus (user of buses pay much less than they are willing to) at the expense of customer value (the cash flow that is generated over the mass of customers, i.e. customer equity). Hence, the value-to-value-perspective is strongly biased (for more details see Krämer \& Burgartz, 2015).

With regard to the efficiency of a price-matching strategy different evaluations can be found in the literature. On the one hand The Economist refers to experiments in the context of game theory and supports a price-matching as suitable to suppress a price war (The Economist, 2015). On the other hand a dominant supplier is not recommended to follow price reductions of a small player in the market. Genenz, Lopez-Sors and Alencar (2014) argue, "the best possible reaction when the competitor lowers prices is to not change prices". When in doubt, the margin decline by the price reduction might be bigger than by the loss of market share.

Table 5. Options to avoid and terminate a price war

\begin{tabular}{|c|c|c|c|}
\hline & & \multicolumn{2}{|c|}{ Phases / time to act } \\
\hline \multirow{3}{*}{ Way to act } & & $\begin{array}{c}\text { Before price war } \\
\text { (actions to avoid a price war) }\end{array}$ & $\begin{array}{c}\text { During a price war (actions to } \\
\text { terminate a price war) }\end{array}$ \\
\hline & $\begin{array}{l}\text { Price- } \\
\text { elements }\end{array}$ & $\begin{array}{l}\text { - Price segmentation; revenue management } \\
\text { systems; non-linear pricing } \\
\text { - Price differentiation (reduced price } \\
\text { transparency); see Postbus }\end{array}$ & $\begin{array}{l}\text { - Do nothing } \\
\text { - Match price reduction or } \\
\text { follow initiator (with distance) }\end{array}$ \\
\hline & $\begin{array}{l}\text { Non-price-ele } \\
\text { ments }\end{array}$ & $\begin{array}{l}\text { - } \text { (Re-)Organization of pricing competence } \\
\text { - Design a monitoring system to track customer } \\
\text { perceptions and loyalty } \\
\text { - Differentiation (quality, service) }\end{array}$ & $\begin{array}{l}\text { - Signaling (see Deutsche Bahn) } \\
\text { - Differentiation (quality, service), see } \\
\text { Postbus (emphasis on quality) }\end{array}$ \\
\hline
\end{tabular}

\subsection{Non-Pricing Measures}

In addition to price measures, it may be useful to illuminate other areas of operational marketing. For example, the pricing processes and decision-making powers should be checked. As shown, an excessive focus on sale volumes can be problematic and counterproductive. On the basis of a survey of German managers Riekhof and $\mathrm{Ha}$ (2015) come to the conclusion that "sales managers have more influence in pricing than marketing managers, which indeed are usually responsible for the strategic positioning of products and services."

Building up and maintaining a strategic competitive advantage is a key function of the modern marketing manager. Therefore, in a longer perspective, the best measure against price erosion it is to ensure the firm's value proposition, be it by brand, outstanding products, service performance or customer loyalty. The absence of a strong value proposition only increases the temptation to use price as the reliable (and relatively effortless) means to close a sale (Bertini, 2014). Hence, is advantageous for companies to anticipate a situation in which 
there is a sudden price competition. When the Australian telecommunications market was fully deregulated in the late-1990s, state-owned Telstra faced competition for the first time. Understanding costumer needs, and segmenting customers according to their needs and predicted consumers' responses were crucial elements of a defensive marketing, which helped Telstra to survive in a more competitive market environment (Roberts, 2005).

The basic behavioral options in a price war can be shown by the classic "prisoner's dilemma": A provider (A) and its competitor (B) decide to set prices at a low or high level. In case, one of the two suppliers offers a low and the other supplier a high price, the company with the low price wins a large market share-the high-priced supplier must be satisfied with the lower market share. As a defensive reaction to this negative scenario, price wars therefore commute usually at low rates for both providers. This leads to a more uniform distribution of the market-but at the expense of the monetary market volume, which significantly decreases due to the low price levels. However, under an environment that allows information exchange between competitors, the dominant strategy is to keep prices high. This is where signaling comes into play (Wilger \& Krämer, 2005). Figure 3 presents an example for signaling: Deutsche Bahn's advertising includes a hint towards the volume of cheap ticket (m 2.4 tickets sold), which is not only relevant for potential customers, but also for competitors (Krämer, 2015c; see Note 7).

\section{Discussion}

Taking into account the more concise definition of the term "price war" it can be stated, that relevant conditions are fulfilled in the case of intercity bus connections in Germany: (1) Megabus as the market entrant tries to win market share by utilizing aggressive pricing, (2) prices are undercut to fall below the level of profitability (at least for main players in the market) and (3) actions are driven by suppliers rather than consumers.

The focus of marketing decision-makers on existing capacities (which is often related to high fixed costs), and the desire to utilize those better and more effectively, at the end leads managers into a decision dilemma. For short-term decisions, pricing specialists often assume marginal costs to be close to zero. This implies strong potential price cuts as they are possible by using a revenue management system (Ryanair is good example: the airline is famous for offering tickets for $€ 5$ with limited availability) or aggressive price promotions. Although, with a medium to long-term perspective all the cost components have to be regarded as variable and must be covered. A scenario of "Zero-Marginal-Costs" is often misleading and counterproductive for positioning.

In addition to the existence of overcapacities, increasing commoditization is a severe threat, since it leads to a perceived similarity between the products and thus a stronger price comparability and transparency. This increases the pressure on the management.

The opportunities to make the right decisions when a price war has been started are limited in the short term, therefore a longer-term strategy and preparation is required. Traditionally, management decisions have a strong focus on parameters as market share (volume strategy) or cash flow (liquidity and profit strategy), but other parameters have to be drawn into the equation as well. This concerns the long-term CRM and customer strategy (Krämer \& Burgartz, 2015). One facet is to examine the price wars' impact on price image of competitors and the price sensitivity of the customers. Thus, some authors discuss an increase in price sensitivity in the market following strong price reductions (see Van Heerde, Gijsbrechts, \& Pauwels, 2008 for retail and Krämer, 2015b, for bus and rail journeys). Once consumers pay unexpected low prices, this leads to adjusted price expectations and an enduring reduced willingness to pay.

Furthermore the correct use of the term "price war" is important. Not every price cut is a price war and should be described in the public that way. Sine price wars are nowadays the rule rather than the exception (Simon, 2013), we hope that we can contribute by suggesting a more precise and focused definition of the term price war. This goes far beyond the "normal" price competition.

\section{Acknowledgments}

The authors are grateful to Rogator AG, Nuremberg, for the provision of survey software, the programming of the questionnaire and the complete data management including access to the online panel. Many thanks also Dr. Gerd Wilger and Dr. Robert Bongaerts (exeo Strategic Consulting AG) for valuable suggestions and substantive input to the study.

\section{References}

Anonymous. (2015). Fernbus-Markt: Rabattschlacht ohne Ende. BizTravel.

Assael, H. (1990). Marketing. Englewood Cliffs. NJ: Prentice Hall.

Bertini, M. (2014). Price Wars and the Managers Who Start Them. Business Strategy Review, 25(4), 14-17. 
http://dx.doi.org/10.1111/j.1467-8616.2014.01122.x

Busse, M. R. (2000). Firm Financial Conditions and Airline Price Wars. Working Paper, Yale School of Management, New Haven, CT. http://dx.doi.org/10.2139/ssrn.237374

Clausewitz, C. V. (1832/1984). On War. Michael Howard \& Peter Paret. Chicester, West Sussex: Princeton University Press Translation.

Genenz, K., Lopez-Sors, C., \& Alencar, R. (2014). Surviving the Price Wars in Emerging Markets: Three Myths and Three Lessons. Pharmaceutical Executive, 38-42.

Gueterverkehr, B. F. (2014). Marktbeobachtung Gueterverkehr: Marktanalyse des Fernbuslinienverkehrs 2014. Bundesamt für Güterverkehr.

Heil, O. P., \& Helsen, K. (2001). Toward an Understanding of Price Wars: Their Nature and How They Erupt. International Jounal of Research in Marketing, 18(1-2), 83-98. http://dx.doi.org/10.1016/S0167-8116(01)00033-7

Heil, O. P., \& Helsen, K. (n. d.). An Investigation into the Phemenon of Price Wars. Working Paper.

Krämer, A., \& Jung, M. (2014). Zwischen Preiswettbewerb und Preiskampf - Das Spannungsfeld zwischen Nachfrageboom und Preiserosion bei Reisen mit Fernlinienbussen. Internationales Verkehrswesen, 66(4), 58-60.

Krämer, A., \& Burgartz, T. (2015). Customer Value Controlling-Combining Different Value Perspectives. Business and Management Studies, 1(2), 11-19. http://dx.doi.org/10.11114/bms.v1i2.814

Krämer, A. (2015a). Pricing in a VUCA World-How to Optimize Prices, if the Economic, Social and Legal Framework Changes Rapidly. In Mack et al., (Eds.), Managing in a VUCA World (115-128). New York: Springer. http://dx.doi.org/10.1007/978-3-319-16889-0

Krämer, A. (2015b). Rabatt-und Kundenbindungskarten im Personenverkehr - Landerubergreifende Analyse zu den Bahn-Rabattkarten in der DACH-Region. ZEVrail, 139(9), 341-347.

Krämer, A. (2015c). Wettbewerbsbeziehungen zwischen Fernlinienbus und Bahn. Presentation. http://dx.doi.org/10.13140/RG.2.1.1640.9683

Krämer, A. (2016). Robustness of Price Perception: How Strong are Anchoring-, Left-Digit- and Framing-Effects when Promoting Sales Offers? Business and Management Studies, 2(1), 35-43. http://dx.doi.org/10.11114/bms.v2i1.1137

Pot, E., Peeters, R., Peters, H., \& Vermeulen, D. (n. d.). Intentional Price Wars on the Equilibrium Path. Retrieved https://www.researchgate.net/publication/228553014_Intentional_price_wars_on_the_equilibrium_path

Rao, A. R., Bergen, M. E., \& Davis, S. (2000). How to Fight a Price War. Harvard Business Review, 78(2), 107-118.

Rogator, E. (2015). Nutzerquote bei Fernlinienbus-Reisen auf $8 \%$ gestiegen-Markt nimmt die angekundigte Fusion von MeinFernbus und FlixBus positiv auf. Retrieved from https://www.rogator.de/fileadmin/Dateien/Unternehmen/Presseinformation-150126-Rogator-exeo-Mobilitae tsTRENDS-2015-Fernlinienbusse.pdf

Roland Berger Strategy Consultants. (2014). Escaping the Commodity Trap-How to Regain a Competitive Edge in Commodity Markets.

Riekhof, H. C., \& Ha, A. (2015). Pricing-Prozesse in der unternehmerischen Praxis. PFH Private Hochschule Gottingen.

Roberts, J. H. (2005). Defensive Marketing-How a Strong Incumbent Can Protect Its Position. Harvard Business Review, 83(11), 150-157.

Smith, G., \& DiPaola, A. (2015). Bloomberg: Saudis' Oil Price War Is Paying Off. Retrieved from http://www.bloomberg.com/news/articles/2015-02-27/saudis-bold-gambit-paying-off-just-three-months-lat er-energy

Simon, H. (2013). Preisheiten - Alles, was Sie über Preise wissen müssen. Frankfurt: Campus.

Simon, Kucher, \& Partners. (2013). Discount is out. Retrieved from http://www.simon-kucher.com/de/news/discount-ist-out 
Schunk, H. (1999). The Evolution of Competitive Interaction. Working Paper, University of Mainz.

Tellis, G. J. (1987). Beyond the many faces of price: An integration of pricing strategies. Journal of Marketing, 50(4), 146-160.

The Economist. (2015a). Abnormally normal. The Economist. Retrieved from http://www.economist.com/node/21678198/print (Accessed 6 December 2015).

The Economist. (2015b). Guaranteed profits-price-match guarantees prevent rather than provoke price wars. The Economist. Retrieved from http://www.economist.com/news/finance-and-economics/21643239-price-match-guarantees-prevent-ratherprovoke-price-wars-guaranteed-profits

Urbany, J. E., \& Dickson, P. R. (1991). Competitive Price-Cutting Momentum and Pricing Reactions. Marketing Letters, 2(4), 393-402. http://dx.doi.org/10.1007/BF00664225

Van, A. M. (2006). Prijzenoorlog Is Over, Maar voor Hoe Lang? Erasmus Food Management Instituut. Retrieved from http://www.efmi.nl

Vanek-Smith, S. (2012). The brave new world of dynamic pricing. Retrieved from http://www.marketplace.org/topics/business/brave-new-world-dynamic-pricing

Van Heerde, H., Gijsbrechts, E., \& Pauwels, K. (2008). Winners and Losers in a Major Price War. Journal of Marketing Research, 45(5), 499-518. http://dx.doi.org/10.1509/jmkr.45.5.499

Von Hirschhausen, C., \& Walter, M. (2008). Potenziale des Fernlinienbusverkehrs. Fachgespräch der Bundestagsfraktion von Bündnis 90/Die Grünen, Berlin, June 2, 2008.

V. C. D. (2014). VCD Bahntest 2014/2015: Die Bahn im Vergleich mit Fernlinienbus und Auto.

Wilger, G., \& Krämer, A. (2005). Richtiges Verhalten im Preiskrieg - Beitrag der Marktforschung für ein angemessenes Pricing im Wettbewerb. Planung \& Analyse, 32(5), 34-38.

Zhang, Z. J. (2010). The Art of Price War: A Perspective From China. International Journal of China Marketing l(1), 17-30.

\section{Notes}

Note 1 . The cost of pumping a barrel of oil out of the ground depends on a variety of factors, including the size and accessibility of the field. Saudi Arabian crude is the cheapest in the world to extract because of its location near the surface of the desert and the size of the fields, which allow economies of scale. Estimated production costs for oil range from $\$ 6$ to $\$ 28$ per barrel. At the beginning of 2016 oil prices fell below $\$ 30$ per barrel.

Note 2. In order to operate a long-distance bus economically, the industry experts surveyed by Federal Office for Transportation of Goods estimated a net price of an average of 5-6 Euro Cent per passenger kilometer (average capacity utilization of the vehicles) as necessary for a sustainable business model. According to other estimates production costs based on an average utilization rate of the buses amount to 4-5 eurocents per passenger kilometer (Krämer \& Rieger, 2015).

Note 3. Prices per kilometer are on average 4-5 Euro Cent on rotes without Megabus competition.

Note 4. As an analysis of available prices by the Internet search portal Fernbusse.de shows the average ticket prices fell by 1.8 percent compared to last year (2014). The average ticket price covering the most important suppliers in Germany fell in 2015 to 17.33 Euros compared to 17.65 Euros in 2014 (Press release from Dec. 7, 2015).

Note 5 . The break-even is reached at $€ 100$ ticket expenses per year. This offer strongly resembles the customer discount and loyalty card of Deutsche Bahn (BahnCard 25). Once customers own the card, the decision process when selecting a mode of transport is supposed to be influenced in favor of Postbus (for details see Krämer, 2015b).

Note 6. While directly after the merger one out of two respondents saw no clear impact on prices, $35 \%$ expected rising prices in the near future (13\% expected further price cuts).

Note 7. The impact of the factor volume of sold tickets on the overall price perception was examined in detail during an experimental design (Krämer, 2016). One significant finding was, that potential customers did not show a more positive evaluation when the presented advertisement contained information on sales figures (" $2.4 \mathrm{~m}$ tickets sold"). In contrast, such sales figures are crucial information for the management of intercity 
buses. The total amount of bus tickets is approximately $1.3-1.5 \mathrm{~m}$ tickets per month, which is less than the amount of the 19 Euro-tickets sold by DB during the campaign. After DB repeated the $€ 19$-ticket campaign in October and November 2015 Megabus initiated a special campaign and announced to offer 50,000 tickets for zero Euro ( $+€ 0.5$ booking provision) in January 2016.

\section{Copyrights}

Copyright for this article is retained by the author(s), with first publication rights granted to the journal.

This is an open-access article distributed under the terms and conditions of the Creative Commons Attribution license (http://creativecommons.org/licenses/by/3.0/). 